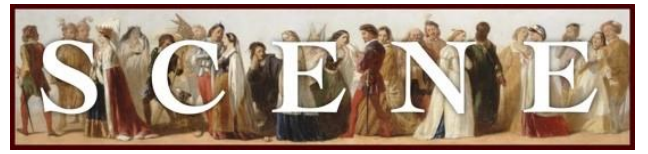

\title{
Nothing is Good without Respect
}

\author{
by Ronda Arab. Written on 2017-10-24. Published in 2017 Issue 2.
}

For the production: The Merchant of Venice (2017, Bard on the Beach, Canada). See production details at the end of the review.

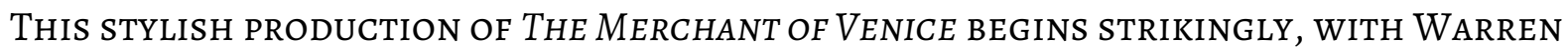
Kimmel's Shylock, rather than Antonio, speaking the first line: "In sooth I know not why I am so sad." Antonio then speaks the same dialogue, drawing together the two "merchants" of Venice around whom the main conflict coheres until finally, the entire cast joins together to speak the words. Although most of the characters in this production of The Merchant of Venice are not sad per se, perhaps because sadness is too honest and complex an emotion for this superficial group, the opening works well to set the tone of a play that offers little happiness for anyone.

Shylock is the saddest character in this production, and an aura of gloom and sorrow surrounds him. Antonio, on the other hand, is never actually morose, despite the text's insistence on his melancholy. Antonio doesn't mope, he sneers; he is angry and superior, not sad. The relationship between him and Bassanio is cast strictly on the "bros" end of the homosocialhomoerotic spectrum, and thus lacking in even the chemistry of a deeply invested masculine friendship. When Antonio kisses Bassanio after the judgement that will kill him, it's a shock to the audience-and to Bassanio. Bassanio's stiff body language, complete with arms flung out in surprised, unwilling surrender, suggests he's never considered that Antonio loves him. This is a choice, but a puzzling one. The invisibility of Antonio's love doesn't accord well with Solania's assessment that Antonio "only loves the world for him [Bassanio]," and it doesn't help us understand why Antonio would enter into a dangerous contract with a man he actively despises and scorns. We see nothing to explain his passive eagerness (and the oxymoron surely applies) to make himself a martyr for his friend. A palpable bond between Antonio and Bassanio is necessary to explain why Portia not only desires to save her husband's friend from judicial murder but needs to save Antonio in order to have a fighting chance at a marriage in which she matters. If Antonio dies by Shylock's knife, he owns Bassanio, and he'll haunt their marriage forever. After Portia has accomplished her tidy intervention, it is she who now owns Antonio. 
In many other ways, however, Nigel Shawn Williams's production is smart and thoughtful. Triangulated character blockings mirror the triangular set up of the three caskets and thematically enhance the Antonio-Bassanio-Portia love triangle. Trendy, contemporary costumes use fashion as insight into character, and a number of the outfits (and especially the shoes) offer a bit of eye-candy to relieve the overall bleakness of this difficult play. Video projections turn the two-story stone columns of the set into the leafy lushness of Portia's Belmont estate, and the second floor of one column is used effectively for extra-textual scenes staging Shylock's sorrow, while at the street level the Venetians, Solaria, and Solania, mock his losses. Here above the stage, as well, Shylock mournfully chants the Kaddish, in response to the betrayal of his daughter, Jessica. Williams's production diminishes the underlying antiSemitism in Shakespeare's play by sympathetically casting Shylock as sad and dignified, playing up the character's moments of humanity, rather than playing a caricature of the Jewish moneylending villain. But there is no shying away from the virulent anti-Semitism of the Venetians, nor from their overall nasty shallowness. Salaria and Solania are indifferent to, even bored by, Shylock's "Hath not a Jew eyes?" speech. The court scene is excruciating, as it should be: spit flies, along with insults, slurs, and Nazi salutes. Shylock wipes saliva from his face without flinching and insists on his bond. When Shylock is crushed, Gratiano laughs and Antonio looks smug. Nor does Williams allow the marriage plot to be a happy romantic confection, as it is sometimes played. In Bassanio's first speech about Portia, he exclaims excitedly about how rich she is; that she is also "fair" is acknowledged afterward, as a distinctly secondary consideration. Gratiano sidles up to Salaria for sensuous kisses both before and after he is married, and harshly denigrates the ring Nerissa gave him during their strikingly bitter quarrel. Bassanio is flippantly nonchalant to Portia about giving away her ring, and then vehemently defensive of his actions. Lorenzo's behavior to the anxious and unhappy Jessica borders on abusive.

Unfortunately, while the often loud and emphatic style of the production creates some good, fun, romping moments--and some deeply disturbing ones such as in the court scene--this style leads to some missed opportunities. Portia, appropriately haughty and regal, conveys genuine distress at the marital predicament she has inherited from her father, who, with the arbitrary power of a good patriarch, stipulated that she must marry the chooser of the right casket. When Portia and Nerissa break the tension by gleefully mocking the long list of Portia's unsuitable suitors, however, I badly wanted their extended merriment to be marred or shadowed just for a moment with remembrance of what's at stake-that Portia, with her beauty, wit, intelligence, and wealth, could be tethered forever to any one of the woefully inadequate suitors she finds so easy to scorn. Except in the trial scene, this production is generally not good at interrupting action and emotion with subtle gestures or quiet moments, 
and when the volume is notched down, the effect, at times, is to create a stage arid of all affect. Perhaps the lack of real emotion on the part of the shallow Venetians, until the profound hatred expressed at the trial, is a conscious directorial choice; if this is the case, it explains the reliance on big gestures rather than intimate ones, that characterize, for instance, the bargaining scene between Shylock, Bassanio, and Antonio. Here the triangulated blocking of the three men forecloses intimacy during a negotiation that should vibrate with the deeply personal agendas and emotional investments that are at stake.

The absence of affect was also a problem during Bassanio's choice of casket, made more noticeable since I viewed the play twice over a ten-day period. At the first performance I attended, Olivia Hutt's expressive face spoke to Portia's excitement when Bassanio chose the correct casket that contained her picture, but while he read the scroll it contained, he barely looked at Portia. The lack of chemistry, physical intimacy, or even proximity between the two supposedly relieved young gentles, now engaged and set for life with a suitable partner, took the drama out of the scene and rendered it a stagnant recitation of Shakespeare's text. This same section had altered to very good effect when next I saw the play roughly ten days later. This time, Portia brought in much more physical movement, speaking her "One half of me is yours, the other half yours" line with tangible, yearning desire. Pushing toward Bassanio and beyond the confines of her blocked space on the stage, Hutt's Portia jumped up and down just enough when Bassanio opened the right casket. Bassanio hadn't changed his affect much in this later production, but now it worked to illustrate that his lesser emotional investment in the marriage is an obstacle Portia alone could overcome.

Hutt's Portia and Kimmel's Shylock offered the most nuanced acting in the production, but a few of the minor characters offered equally notable performances. Nadeem Phillip as Morocco is amusing without ever falling into caricature, and, as the judge on the first night I attended, Phillip ad-libbed hilariously with a gavel slamming reprimand to an audience member who chose to be rowdy while Portia silently read the decree. Kate Besworth's principal role is as Solania, but later she also plays Beatrice, Portia's dim waiting woman in Belmont, stealing the stage during her brief, vague and confused appearances. Paul Moniz de Sá as Tubal, with the subtlest of intimations, conveys alarm as he recognizes what Shylock is conceiving as revenge, his quiet gesture repeated for both performance confirming the focused intention of the actor.

The production ends as well as it begins, focusing the spotlight on Portia and replacing the bawdy sexism of the original text's ring joke with thoughtful words befitting the compromised "happy" ending of this problematic play. "Nothing is good, I see, without respect," Portia opines ruefully. Indeed. 


\section{Production Details}

\section{General}

Title

Year

Theater Company

Theaters

\section{Cast}

SHYLOCK
ANTONIO
BASSANIO
PORTIA
NERISSA
DUKE OF VENICE
PRINCE OF MOROCC
PRINCE OF ARAGON
SOLANIA
GRATIANO
SALERIO
LORENZO
JESSICA
TUBAL
LAUNCELOT GOBBO
LEONARDA
BALTHASAR
MESSENGER
BEATRICE

\section{Creatives}

Director
Directing Apprentice
Costume Designer
SCEnic Designer
Lighting Designer
SOUND Designer
Fight Director
Stage MANAgER
Assistant Stage MANAgER

NigEL SHAWN Williams

PaUl MONIZ DE SÀ

DREW FACEY

ADELE NORONHA

ADRIAN MUIR

CARMEla SisON

JOSHUA REYNOLDS

JOANNE P.B. SMITH

RUTH BRUHN 
Apprentice Stage Manager

HEAD VOICE \& TEXT COACH

PROJECTION DESIGNER
JENNIFER STEWART

Alison MatTHEWS

ChIRAg NAIK 